\title{
ACADEMIC ENTREPRENEURSHIP: AN EMPIRICAL RESEARCH OF INVENTION COMMERCIALISATION
}

\author{
Doanh, D.C., Bernat, T., Hieu, N.T., Ngoc, N.B., Linh, N.T.P.
}

Duong Cong Doanh / National Economics University, Faculty of Business Management, 207 Giai Phong, Hai Ba Trung, Hanoi, Vietnam. Email: doanhdc@neu.edu.vn

Tomasz Bernat / University of Szczecin, The Faculty of Economics, Finance and Management, 64/430 Mickiewicza Street, 71-101 Szczecin, Poland. Email: Tomasz.bernat@usz.edu.pl

Nguyen Thanh Hieu / National Economics University, Faculty of Business Management, 207 Giai Phong, Hai Ba Trung, Hanoi, Vietnam. Email: nguyenthanhhieu2002@yahoo.com

Nguyen Bich Ngoc / National Economics University, School of Trade and International Economics, 207 Giai Phong, Hai Ba Trung, Hanoi, Vietnam. Email: bichngocktqt.neu@gmail.com

Nguyen Thi Phuong Linh / National Economics University, Faculty of Business Management, 207 Giai Phong, Hai Ba Trung, Hanoi, Vietnam. Email: plinhkt@gmail.com

\begin{abstract}
Empirical studies exploring particular mechanisms that the country's institutional profile, such as regulatory and normative dimensions are internalised into scientists' cognitive process of commercialising their research results, are rather sparse. This study aims to develop a conceptual framework in which integrated the lens of institutional theory and theory of planned behaviour to empirically test and discover the effects of regulatory and normative supports on scientists' intention to commercialise an invention. A survey was conducted at institutions and universities using stratified random sampling from 255 scientists during the period of 2 months from May to July 2020. Structural equation modelling was employed to estimate the paths and correlations. Results revealed that although regulatory support was not found to have a direct role in shaping intention to commercialise the invention, it had more influences and significances in the increase of attitude towards entrepreneurship, subjective norms, perceived behavioural control. Also, attitude towards entrepreneurship and perceived behavioural control were found to be full mediators in the linkage between regulatory support and intention to commercialise the invention, but subjective norms were not. Besides, normative support, although it was not related to subjective norms, it had direct influences on attitude toward invention commercialisation, perceived behaviour control, and intention to commercialise the invention. Thus, attitude toward invention commercialisation, perceived behaviour control was figured out to play a partially mediating role in the relationship between normative support and intention to commercialise invention among scientists. This research shows that new institutions that address younger generations and concentrate on enhancing entrepreneurial qualities are crucial to foster commercialisation in emerging economies. Also, by representing outstanding issues, our research encourages further debate and research activities.
\end{abstract}

Implications for Central European audience: Even though the research results are related to academic entrepreneurship in Vietnam, the findings of this study can advocate that to 
promote academic entrepreneurship in emerging economies, enhancing both regulatory and normative supports are really necessary. In addition to theoretical contributions, this study also has several practical implications for researchers and policymakers in Central Europe.

Keywords: academic entrepreneurship; invention commercialisation; regulatory and normative supports, a theory of planned behaviour

JEL Classification: L26, L24, M13

\section{Introduction}

Technology transfers are viewed as a process of implementing research results to practices, whereas technology transfers relating to financial exchanges are defined as commercialisation (Nguyen et al., 2018). Thus, invention commercialisation can be determined as an entrepreneurial activity since it refers to converting results of research into new products or processes for commercial exchange (Alshumaimri et al., 2012; Teixeira \& Nogueira, 2016). Thus, two concepts of invention commercialisation and entrepreneurship are used interchangeably.

Knowledge spillovers generated by scientific researches could be found as a vital factor for economic growth, creation of jobs, and global competitiveness in the context of internationalisation, the systematic underestimating of economic and social spillovers driving from scientist research commercialisation might bring on rigorous policy distortions (Aldridge \& Audretsch, 2010). In the last few decades, a number of entrepreneurship literature, both theoretical and empirical, has been developed in order to discover entrepreneurial behaviours for the general population (Aldrich \& Martinez, 2010). However, recent studies have started to distinguish academic entrepreneurship as a distinct case that is different from the more general population (Aldridge \& Audretscg, 2010; Alshumaimri et al., 2012; Monsey \& Wright, 2007; Phan \& Siegel, 2006; Link et al., 2007). Academic entrepreneurship in the context of this proposal refers to scientists who are broadly involved in the process of commercialising their results of studies or inventions (Alshumaimri et al., 2012). So, it is necessary to investigate which factors are conducive to academic entrepreneurship or which factors become barriers to academic entrepreneurship.

In addition, although the importance of entrepreneurship has been acknowledged (Liñán et al., 2011), the role of contextual variations in discovering entrepreneurial intention and behaviour has been emphasised by many entrepreneurship scholars (Davidsson, 1995; Liñán \& Chen, 2009; Mueller \& Thomas, 2001; Hayton et al., 2002; Vancea \& Utzet, 2017). Moreover, efforts to foster entrepreneurial activities, especially academic entrepreneurship, have been interested in both developed and developing countries, consisting of supported policy and programmes by governments in many countries, some have had a positive effect, while others only have met with partial success (Baughn et al., 2006; Reynolds et al., 2001; Vodopivec, 1998). The different outcomes of such efforts might reflect inadequate awareness of the part of policymakers involving necessary drivers of entrepreneurship in diverse country contexts (Baughn et al., 2006). Thus, understanding why and how scientists commercialise their inventions may promote academic entrepreneurship more effectively and efficiently. Besides, Baugh et al. (2006) argued: "historical, cultural, economic and political contexts in different countries may shape the normative, social and cognitive underpinnings of entrepreneurship". So, the overall objectives of the study are to discover the specific 
mechanisms in which contextual factors are internalised into scientists' cognitive process of invention commercialisation in Vietnam.

Contributions of this study on entrepreneurial literature are represented in three manners. Firstly, the direct effects of normative and regulatory supports on scientists' intention of invention commercialisation are investigated. Secondly, the mediating roles of three antecedents in the theory of planned behaviour in the linkage between regulatory and normative dimensions and intention to commercialise inventions are illustrated. Thirdly, even though the findings are involved in academic entrepreneurship in Vietnam, the results of this study might advocate that to promote invention commercialisation activities of emerging economy markets in Central Europe. Finally, besides the theoretical contributions, this study also brings several practical implications for entrepreneurs, policymakers and researchers as well.

\section{Literature review}

\subsection{Research on invention commercialisation at individual and institutional levels}

Studies on invention commercialisation have been considered at two levels, namely individual and institutional. At the individual level, the processes and success of research commercialisation are significantly influenced by individual characteristics of scientists because invention commercialisation depends considerably on the scientists' competencies in recognising and catching the business opportunities from invention or research results (Nguyen et al., 2018). Some previous studies have indicated that social network (Aldridge \& Audretsch, 2010; Bercovitz \& Feldman, 2008; Haeyssler \& Colyvas, 2011; O' Gorman et al., 2008), prior knowledge (Shane, 2000), human capital (publications) (Alshumaimri et al., 2012), age (Bercovitz \& Feldman, 2008; Link et al., 2007) and gender difference (Elston \& Audretsch, 2010; Markman et al., 2008; Minniti \& Nardone, 2007; Perkmann et al., 2013) have effects on the ability to recognise business opportunities, determine these type of opportunities and decision to commercialise the invention.

Specifically, male scientists are more likely to be entrepreneurial (Markman et al., 2008; Perkmann et al., 2013), while seniority and commercialisation have a positive correlation (Perkmann et al., 2013). Alshumaimri et al. (2012) investigate that human capital, which is measured by publications, is more conducive to academic entrepreneurship, whereas Shane (2000) indicate that prior knowledge and experiences have significant effects on discovering business opportunities because, with only one invention, six scientists realised different business opportunities. In addition, Aldridge and Audretsch (2010) state that social network plays an important role in affecting which scientists commercialise invention and/or research results and which scientists abstains from entrepreneurial behaviours, while O' Gorman et al. (2008) stress that social network and business experience of researchers have the strong correlation with the success of invention commercialisation. Moreover, some studies show that scientists' motivation to commercialise the research results is greatly influenced by research achievements and stages of career (Aldridge \& Audretsch, 2010; Dechenaux et al., 2011). At the mature stage, some scientists with excellent research achievement and reputation are more interested in invention commercialisation activities while younger scientists, who are at the early stage of their career, are more interested in building science reputation (Aldridge \& Audretsch, 2010). 
However, studies on invention commercialisation at the institutional level are rather sparse (Perkmann et al., 2013), and almost all these studies are conducted in advanced economies (Nguyen et al., 2018). Some studies had shown that commercialisation had been facilitated by the presence of clear national policies, such as the Bayh-Dole Act in the United States (Aldridge \& Audretsch, 2011) and the abolition of the so-called "professor privilege" in European countries (Mowery \& Sampat, 2005; Powevers \& McDougall, 2005). Researching commercialisation in emerging economies is also started to be interested recently, such as Saudi Arabia (Alshumaimri et al., 2012), Malaysia (Yaacob et al., 2011), China (Li \& Morgan, 2010) and Vietnam (Tran, 2007). Nevertheless, the lack of strong supports from market institutions, experiences and necessary resources is becoming the key barrier and tremendous challenge for invention commercialisation in these countries (Alshumaimri et al., 2012; Nguyen et al., 2018; Shapira \& Wang, 2009; Tran, 2007).

Some scholars have agreed that institutional factors are internalised by individual researchers to shape their cognitive process of invention commercialisation (Bercovitz \& Feldman, 2008; Lam, 2011; Nguyen et al., 2018), while invention commercialisation entails individual scientists ensuring their own entrepreneurial acts (Aldridge \& Audretsch, 2011; Hayter, 2015; Shane \& Venkataraman, 2000). However, the detailed mechanisms in which scientist's individual cognitive processes internalise contextual factors have not been answered clearly. For instance, although scientists' motives for commercial engagement could be multifaceted (Lam, 2011), the question "how do contextual factors facilitate the process of scientists' entrepreneurial cognitions or invention commercialisation?" are not explained evidently (Nguyen et al., 2018). Indeed, Turker \& Selcuk (2009) argue that most recent studies only focus on examining the role of some internal factors such as personal characteristics (Akanbi, 2013; Antoncic \& Prodan, 2008), individual motivations (CameloOrdaz et al., 2016; Kautonen et al., 2013; Tkachev \& Kolvereid, 1999) and personal background (Bird \& Brush, 2002; Boden \& Nucci, 2000; Camelo-Ordaz et al., 2016; Long \& Quan, 2018) rather than investigating the influence of external factors on shaping entrepreneurial intention. Also, Henderson and Robertson (2000) state that an individual' entrepreneurial perception is mostly driven by their innate characteristics. However, scholars have reached a consensus that entrepreneurial traits should be nurtured by external factors (Henderson \& Robertson, 2000; Turker \& Selcuk, 2009). Thus, contextual (environmental) factors that are determined as regulatory and normative elements (North, 1990, 2005) can play a crucial role in configuring entrepreneurial intentions, even actual business venture behaviours (Kruja-Demneri, 2020). In other words, both of them might have significant influences on an individual' cognitive process of entrepreneurship.

\subsection{Theory of Planned Behaviour}

Krueger \& Carsrud (1993) have shown that the process of entrepreneurial cognition can be explained by the theory of planned behaviour, which was developed by Ajzen (1991), because "intention entails an enactive cognitive process which serves to channel beliefs, perception and other exogenous factors into the intent to act, then to the action itself" (Krueger \& Carsrud, 1993, p. 315), while Bird and Jellinek (1988) described entrepreneurial intention as the level of cognitive awareness related to starting a new business. Also, according to the Social Learning Theory, contextual factors have a great impact on learning and higher cognitive processes (Bandura, 1977). Thus, in this proposal, we combine the contextualisation view of entrepreneurship (Gartner et al., 1992; Gupta et al., 2014; Busenitz 
et al., 2000; Turker \& Selcuk, 2009) on entrepreneurial cognitions (Ajzen, 1991) to develop a conceptual framework in order to investigate the correlation between contextual factors and scientist's cognitive process of invention commercialisation (from the attitude towards invention commercialisation, subjective norms and perceived behavioural control to intention to commercialise invention). Liñán et al. (2011) also argue that based on the theory of planned behaviour (Ajzen, 1991), people take their entrepreneurial decision inspired by three motivational factors, including attitudes toward the behaviour, subjective norms and perceived behavioural control. Attitude towards the behaviour reflects the degree to which an individual has a favourable or unfavourable assessment of a particular behaviour; it also depends on an individual' evaluation of the expected results/outcomes of the behaviour. Subjective norms relate to the perception of social pressures by an individual to perform or not perform a specific behaviour. It reflects an individual's perception in terms of salient people encouraging or discouraging to carry out a particular behaviour. Perceived behavioural control refers to the beliefs about easiness or difficulty in carrying out a specific task. It also shows the perceptions of the availability of resources, supports or barriers to carry out the behaviour. The theory of planned behaviour probably can be implemented to any behaviours which require a particular amount of planning. Thus, this theory has been reliably proved robust in explaining intentions and behaviours in various fields of research. The decision to commercialise invention or become an entrepreneur is a complex one. It is also seen as a result of intricate mental processes. Based on this sense, the theory of planned behaviours of Ajzen (1991) has been frequently applied to explain this mental process leading to entrepreneurial acts (Liñán, 2008).

In light of previous studies, we would propose a research model to investigate Vietnamese scientists' cognitive process regarding commercialising invention under the effects of contextual factors. The planned behavioural theory provides an overall framework to analyse the entrepreneurial intention of an individual (Fishbein \& Ajzen, 1980; Ajzen, 1987, 1991; Turker \& Selcuk, 2009). Entrepreneurial intention is perceived as an essential and fundamental condition to be a nascent entrepreneur, whereas entrepreneurship is determined as the emergent process of an organisation (Gartner et al., 1992), an individual's intention to pursue an entrepreneurial career is crucial to this process (Lee et al., 2011). Moreover, the entrepreneurial intention is considered the first step in a series of activities to found an organisation (Bird, 1988), yet Fishbein \& Ajzen (1975) argued that intentions toward a behaviour could be seen as important indicators of that behaviour. In other words, intentions are still seen as the best predictor of individual behaviour (Krueger et al., 2000). Also, Shapero \& Sokol (1982) describe that the entrepreneurial intention stems from the perceived feasibility and desirability of a person and that is influenced by contextual factors such as culture, society and structure.

Numerous research on business ventures has shown the relationships between three attitudinal components (attitude towards entrepreneurship, subjective norms and perceived behavioural control) and intention to become an entrepreneur (Kolvereid, 1996; Krueger et al., 2000). Nevertheless, existing literature on direct influences of subjective norms on entrepreneurial intention is rather inconsistent. While some studies argue that the linkage between subjective norms and entrepreneurial intention is significant (Kolvereid, 1996; Othman \& Mansor, 2012; Maresch et al., 2015), others found this relationship is not empirically supported (Autio et al., 2001; Krueger et al., 2000; Miranda et al., 2017). The following hypothesis proposed to test the linkages between attitude towards invention 
commercialisation, subjective norms, perceived behavioural control and intention to commercialise inventions among Vietnamese scientists.

H1: Intention to commercialise invention is positively related to (a) attitude towards invention commercialisation, (b) subjective norms and (c) perceived behaviour control.

H2: Subjective norms is positively related to (a) attitude towards invention commercialisation; and (b) perceived behaviour control.

\subsection{Country Institutional Profile and Scientist Entrepreneurship}

The concept of the country institutional profile, which includes regulatory and normative dimensions, was used to investigate how a specific country's government policies and value systems influence domestic business activities (Busenitz et al., 2000; Kostova, 1997). Busenitz et al. (2000, p. 995) have defined regulatory support as "laws, regulations, and government policies that provide support for new business, reduce the risks for individuals starting a new company, and facilitate entrepreneurs' efforts to acquire resources". Rulesetting, controlling, monitoring, and even approving activities are included in the regulatory processes (Gupta et al., 2014; Scott, 1995; Urban, 2019). Enterprises can take advantage of resources that are available through the sponsored and/or supportive programmes of governments. Also, entrepreneurs can capture opportunities steaming from policies proposed by governments (Pinho \& de Lurdes Martins, 2020; Rondinelli \& Kasarda, 1992; Urban, 2019). Thus, government policies are likely to encourage scientists to commercialise their inventions by allowing inventors to be legally integrated into ease or protecting them from intellectual property rights infringement. In other words, the regulatory dimension, which can be determined as the most formal of elements in a country's institutional profile (Bruton \& Ahstrom, 2003), can significantly affect scientist's cognitive process of invention commercialisation.

Moreover, the normative support refers to "the degree to which a country's residents admire entrepreneurial activity and value creative and innovative thinking" (Busenitz et al., 2000, p. 995). It consists of "social norms, values, beliefs, and assumptions about human nature and human behaviour that are socially shared and carried by individuals" (Alvarez \& Urbano, 2012). Some prior studies confirmed that the normative dimension has an effect on business venture activities (Baughn et al., 2006; Oftedal et al., 2017; Turulja et al., 2020). Spencer \& Gomez (2004) suggested that the degree that a society's residents respect business activities or admire entrepreneurs might be a predictive factor of entrepreneurship more exactly than general dimensions of culture. Normative support, therefore, can play a significant role in shaping the intention to commercialise inventions among scientists.

Recently, both qualitative and quantitative studies showed that the institutional environment played a key role in fostering entrepreneurial activities (Hoppmann \& Vermeer, 2020; Nguyen et al., 2018; Nowiński et al., 2020; Perkmann et al., 2013; Shirokova et al., 2020; Urban, 2019). Indeed, the country institutional profile, including regulation, laws, rules, formal and informal norms, serve as a major reference of business venture activity in any society (Gupta et al., 2014; Chiles et al., 2007). The perceived institutional profile might be conducive to business venture behaviour throughout certain and viable actions. A motivated system, integrated with normative norms, can significantly affect the entrepreneurial intention and behaviour (Gupta et al., 2014; Peng \& Zhou, 2005), especially academic entrepreneurship or invention commercialisation (Nguyen et al., 2018; Nguyen et al., 2020). When the institutional 
profile of a country is favourable for stimulating entrepreneurial activities, individuals' entrepreneurial efforts are able to become actual behaviours (Bruton et al., 2008). Veciana \& Urbano (2008, p. 373) confirmed that "the process of becoming an entrepreneur is highly conditioned by the formal and informal institutions", however, they also emphasised that in the entrepreneurship literature, how the institutional environment influence-foster or hinderthe emergence of nascent entrepreneurs, the development of new firms, and even business performance of these enterprises. Therefore, institutional context establishes the essential conditions for personal decision-making, that acts as a catalyst for entrepreneurial cognition and the quality of business venturing (Chowdhury et al., 2019; Sobel, 2008) and "institutional framework within which an activity is performed often determines whether this activity is productive, unproductive or destructive" (Douhan \& Henrekson, 2010, p. 630). Analogously to prior researches (Gupta et al., 2014; Nowiński et al., 2020; Pinho \& de Lurdes Martins, 2020; Urban, 2019), intrinsically this study assess scientists' perceptions of the institutional environment, which consists of perceived regulatory and normative supports, on the shaping their cognitive process of invention commercialisation.

Misoska et al. (2016) state that institutional context, which consists of regulatory and normative supports, can have positive or negative influences on attitude towards entrepreneurship because individuals' perception of regulations, laws, social and cultural values can result in their positive or negative assessments of entrepreneurship. In addition, the business environment is found to have a strong correlation with perceived behavioural controls and entrepreneurial intention of Spanish university academics (Miranda et al., 2017). Academics also are interested in support of government policy, characteristics of local business context, and the support mechanisms of universities/institutes (Goel et al., 2015; Moog et al., 2015; Foo et al., 2016). Also, normative norms also can be correlated with an individual's perceived behavioural control because when citizens in the society admire entrepreneurs and entrepreneurial activities, he or she can have higher beliefs/perceptions of easiness in performing a business venture. Luthje \& Franke (2003) state that entrepreneurial intention is dramatically affected by regulatory and normative supports while Turker \& Selcuk (2008) argue that regulatory support not only has the direct influence on entrepreneurial intention but this relationship is mediated by entrepreneurial self-efficacy, which is also considered as perceived behavioural control (Vamvaka et al., 2020). Therefore, the following hypotheses are proposed to test the effects of contextual factors, including regulatory and normative supports, on scientist's cognitive process regarding of commercialising invention, steaming from the attitude towards invention commercialisation, subjective norms and perceived behaviour control to intention to commercialise their inventions.

H3: Regulatory support is positively related to (a) attitude towards invention commercialisation, (b) subjective norms, (c) perceived behaviour control and (d) intention to commercialise the invention.

H4: Normative support is positively related to (a) attitude towards invention commercialisation, (b) subjective norms, (c) perceived behaviour control and (d) intention to commercialise the invention.

Also, this study focuses on exploring the mediating roles of three antecedents in the theory of planned behaviour (Ajzen, 1991) on the relationship between contextual factors and 
intention to commercialise inventions among Vietnamese scientists. Therefore, the following hypotheses are proposed to examine these roles.

H5. Attitude towards invention commercialisation mediates the linkages of intention to commercialise invention with (a) regulatory support, (b) normative support and (c) subjective norms.

H6. Subjective norms mediate the linkages of intention to commercialise invention with (a) regulatory support; (b) normative support.

H7. Perceived behaviour control mediates the linkages of intention to commercialise invention with (a) regulatory support, (b) normative support and (c) subjective norms.

By adopting the planned behavioural theory, we describe the conceptual framework of the proposed study in Figure 1.

Figure 1 | Conceptual Framework

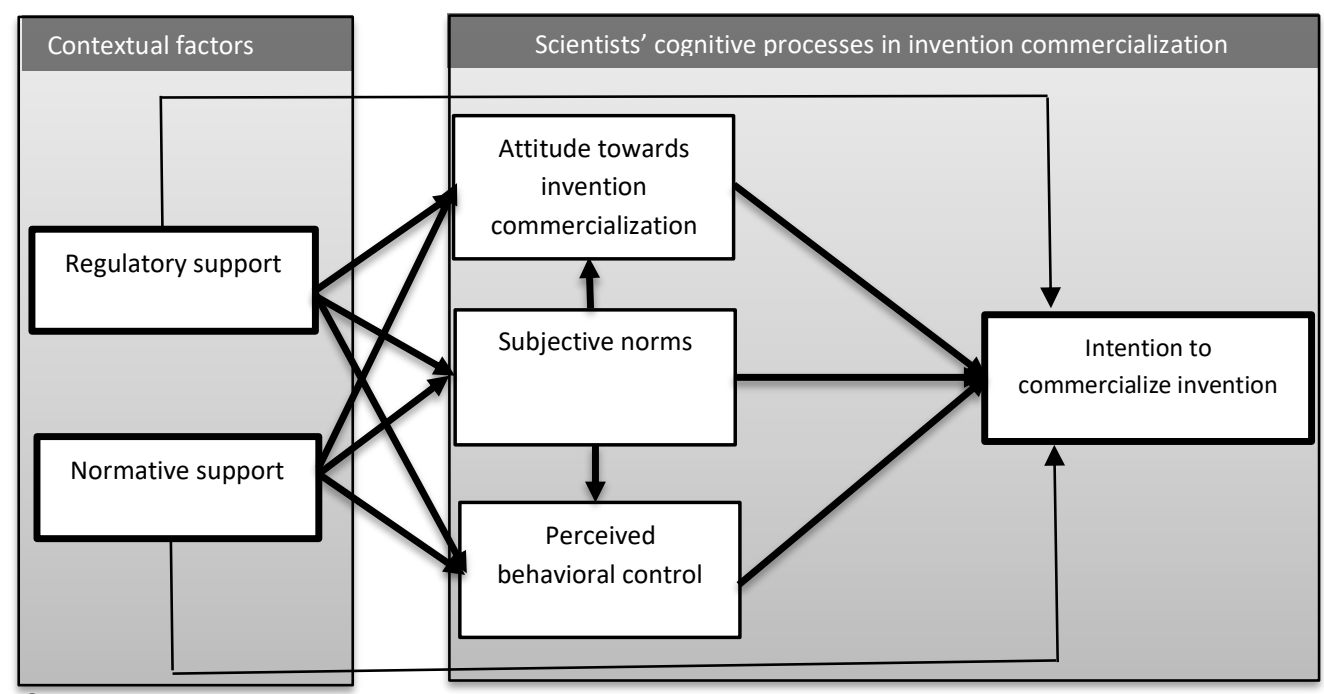

Source: authors

\section{Contextualisation of the research}

Vietnam has transformed from a socialist system (centrally planned and controlled) to "market economy under socialist orientation" since 1986 (Nguyen et al., 2018; Tran \& Kocaoglu, 2009). Like China and some socialist countries, Vietnam had adopted a sort of state capitalism economic model, initially starting in the agricultural and business fields where gardeners and administrators of State-Owned Enterprises (SOEs) along with private-owned firms result in great economic growth with the autonomy of economic activities throughout some economic reforms, which called "Doi Moi" (Kwon et al., 2019). However, the reform of scientific studies and the development of technology, which only began in the middle of the 1990s, was far backwards in comparison with the business sector. Then, the reform in technology and scientific researches was promoted. This resulted in two crucial changes leading to interests in invention commercialisation or academic business venture, including (i) as a result of state budget shortage, the operations of research organisations have been 
encouraged to become more autonomous, and research organisations were also required to create their own revenue throughout their own studies (Tran, 2007); (ii) recently, the government take account into improving the research quality by promoting the international publications. Several national foundations, such as NAFOSTED (The National Foundation for Science and Technology Development) and NFV (Newton Fund Vietnam), and National Innovation Fund (NIF), have been established to fund basic researches, which can be recognised via international publications (Nguyen et al., 2018).

In Vietnam, the policy of promoting private enterprises to conduct innovation activities has freed the science and technology market up. Recently, foreign firms have been employed patents in Vietnam, which resulted in the improvement of a huge body of techniques. Almost all patents were related to areas such as coating, painting, copolymers, methods, devices and systems (Kwon et al., 2019). Also, both public and non-public expenditure on research and development has risen dramatically in recent years. The government has established several new programmes and projects to support the development of high technology products and innovation. That revealed that the Vietnamese government had put efforts to build a supportive ecosystem for innovation and the development of high technology.

Invention commercialisation in transitional economies, such as Vietnam, has to face some difficulties and challenges. Firstly, market-supporting institutions for commercialising invention and research result, which include regulatory, cognitive, and normative dimensions, is only considered at the nascent stage. Thus, it is not always clear in the right proprietary problems (Nguyen et al., 2018), and the contribution to the development of science and technology of some state-funded studies should also be questioned (Tran \& Kocaoglu, 2009). Secondly, the innovation system in Vietnam is fragmented where "supply and demand" information in the science and technology market is non-transparent, and the enforcement of contracts is feeble, as usually happened in transitional economies (Welter \& Smallbone, 2011). Finally, institutes, universities, and even researchers which become more autonomous also result in some awkward situations for both organisational and individual levels. For universities and institutes, they are required to organise more effectively to support research commercialisation properly. Therefore, they are compelled to learn business skills (Nguyen et al., 2020; Phan \& Ho, 2014). For scientists, international publications are determined as the result of research funding, have become more attractive to them regarding both financial and reputation perspectives (Nguyen et al., 2018; Nguyen et al., 2020). However, some implications for commercialising invention or research results can derive from the context of the transitional economy and socialist heritage. Indeed, desires and determinations of scientists/researchers serve as key references for invention commercialisation behaviour within the encouragements of policy and institutional levels. Researchers can enhance their scientific reputation and obtain reasonable finance when they carry out basic research projects and have an international publication from the results of these projects. Thus, not only scientists' experience and reputations could significantly affect how they engage in invention commercialisation, but the institutional profile also might contribute to the process of their cognitive process of academic business venture (Nguyen et al., 2018). 


\section{Method}

\subsection{Participants}

The purpose of the research was to examine whether regulatory and normative supports affect scientists' intention to commercialisation. We believe that a survey methodology was most appropriate for our study because of two main reasons. On the one hand, this approach provides the most detailed perceptions of scientists in terms of regulatory and normative supports for entrepreneurship activities. Thus, this method was often employed to collect data about scientist entrepreneurship in recent studies (Aldride et al., 2014; Aldride \& Audretsch, 2012; Alshumaimri et al., 2012; Nguyen et al., 2020). On the other hand, this approach can be the most feasible in emerging economies, like Vietnam, because there is a lack of systematic data which identifies researchers/scholars along with their entrepreneurial activities (Nguyen et al., 2020).

The data was collected from scientists and professors at institutions and universities in Vietnam. The scientists who held at least a PhD degree and achieved certain success in research (for example, international publications, completed research projects, international and national awards, etc.) are surveyed. Specifically, we sent the questionnaires (online survey) through email addresses directly to researchers or/and scientists who have been working at universities and research institutes in Vietnam. This research employed stratified random sampling to collect data, including three steps. Firstly, two main regions of Vietnam, including Northern and Southern areas with demarcation lines in Quang Trip province, were selected in order to survey. According to the according to Ministry of Education and Training (MOET, 2018), there were 72,700 lecturers who were working at 224 universities/institutes (123 universities in the Northern and 101 in the Southern) in Vietnam. However, only 22.7\% of lecturers held PhD degrees (in order to be included in the sample, scientists need to hold at least a PhD degree). Secondly, in each region, listing universities/research institutes and using simple random sampling to choose universities/institutes for surveying. Specifically, at this stage, 25 universities/institutes in the Northern regions and 20 universities/institutes in the Southern region were randomly selected, that based on the lists of 224 universities and institutes available at the formal website of the Ministry of Education and Training, Vietnam (following the lists of 224 universities/institutes, one out of every five universities/institutes was selected, starting from University of Social Science and Humanities to University of Law). Thirdly, at this final stage, we decide to choose researchers/scientists randomly at each selected university/institute to send the online survey to private email addresses using the collecting list of available email addresses from the formal website of universities/institutes (following the list of available email addresses of lecturers/scientists, 1 out of every ten lecturers, who hold PhD degree, was selected to send the questionnaire). Consequently, a random sampling, including 1369 email addresses, was then chosen to be surveyed basically. Also, we asked the administrative staff at each institute and university to verify the contact information for researchers, then we sent each researcher an email to solicit his/her participation, the link to access the online survey, as well as the detailed instructions on how to fulfil the questionnaires. Reminder emails were also used to send again to non-respondent scientists twice at an interval of one week. The survey was taken from 02 May 2020 to 02 July 2020 (2 months). All participants (scientists/researchers) were informed clearly that they were voluntary to take part in the survey; their answers would have been confidential and secure; the data was only used for academic purposes. Finally, we received fulfilled 
questionnaires from 298 participants, accounting for $21.7 \%$. Compared to online surveyed studies, this rate is acceptable (Cook et al., 2000; Goether et al., 2012). However, before performing the analysis, we excluded 18 respondents because of incomplete data as well as non-serious answers. Moreover, 25 participants were excluded due to no researches/publications conducted, while our study only focused on scientists who intend to commercialise their own research. Finally, the sample included 255 researchers. Although the sample size is rather small (only 255 validated responses), that is appropriate for structural equation modelling (Hair et al., 2010). In addition, the method stratified of random sampling can increase the representativity of the sample (Salkind, 2010). Thus, the confidentiality and representativity of the sample were guaranteed.

Table 1 | Demographic characteristics of scientists

\begin{tabular}{|c|c|c|c|}
\hline Variables & & $\mathbf{N}$ & $\%$ \\
\hline \multirow{2}{*}{ Gender } & Male & 186 & 72.94 \\
\hline & Female & 69 & 27.06 \\
\hline \multirow{4}{*}{ Age } & Less than 25 years old & 5 & 1.96 \\
\hline & From 26 to 35 years old & 116 & 45.49 \\
\hline & From 36 to 50 years old & 96 & 37.64 \\
\hline & More than 51 years old & 38 & 14.91 \\
\hline \multirow{4}{*}{$\begin{array}{l}\text { Research } \\
\text { fields }\end{array}$} & Natural sciences & 132 & 51.76 \\
\hline & Engineering & 67 & 26.27 \\
\hline & Economics, law and social sciences & 45 & 17.64 \\
\hline & Other fields & 11 & 4.33 \\
\hline \multirow{2}{*}{$\begin{array}{l}\text { Working } \\
\text { places }\end{array}$} & Worked in a university & 173 & 67.84 \\
\hline & $\begin{array}{l}\text { Working in a non-university research } \\
\text { institution }\end{array}$ & 82 & 32.16 \\
\hline
\end{tabular}

Note: $\mathrm{N}=255$

Source: own calculations

Results reveal that almost all scientists, who participated in the online survey, were male (72.94\%) while only $27.06 \%$ of researchers are female. The largest proportion of scientists aged from 26 to 35 years old $(45.49 \%)$, followed by researchers who were from 36 to 50 years olds (37.64\%), more than 51 years old (14.91\%) and less than 25 years old (only $1.96 \%$ ), respectively. In terms of research fields, more than half of the researchers engaged in natural sciences $(51.76 \%)$ while $26.27 \%$ of participants were involved in the engineering field, and only $17.64 \%$ scientists researched in economics, law and social sciences. Approximately two-thirds were working in a university (67.84\%), whereas 32.16 scientists were working in non-university research institutions. 


\subsection{Data analysis}

We perform a structural equation modelling to assess the effects of contextual factors, including regulatory and normative support, on scientist's cognitive process in commercialising invention and examine the mediating roles of attitude towards invention commercialisation, subjective norms and perceived behavioural control in the relationship between contextual factors and entrepreneurial intention.

Firstly, univariate normality was assessed by using skewness-kurtosis values (Hair et al., 2010); all items in the scales should have a skewness value of lower than 3 and the kurtosis value of less than 8 (Kline, 2005). Secondly, Cronbach's alpha and explorative factor analysis (EFA) were utilised to estimate the internal consistency reliability of each construct. All variables were also able to have an acceptable value when the Cronbach's alpha is higher than 0.63 (Nunnally \& Bernstein, 1994) and the Corrected Item-Total Correlation of each item should be higher than 0.3 (Hair et al., 2010). Finally, the structure equation method (SEM) was conducted following two-stage in this study and several proper analysis techniques was employed to validate the proposed model and to test the research hypotheses. Hair et al. (2006) suggested that SEM allows the researcher to test simultaneously many interrelated relationships between indicators and latent constructs. Thus, confirmatory factor analysis (CFA) (measurement model) should be used at the initial stage of SEM (Byrne, 2010). In addition, the ability of SEM is to validate the associations between latent variables, so structural model analyses should be targeted in the second stage of SEM. All the problems related to dimensionality, validity and reliability of each construct can also be tested separately (Anderson \& Gerbing, 1988; Kline, 2005).

Especially, SEM was conducted using AMOS 22.0 by examining the several fit indices of the hypothesised model, such as CMIN (Chi-square Statistics), CMIN/DF (Chi-Square/Degree of Freedom), CFI (Comparative Fit Index), TLI (Tucker-Lewis Index), GFI (Goodness-of-Fit) (Jang et al., 2018). However, CMIN and CMIN/DF are sensitive to sample size (Jöreskog, \& Sörbom, 1993), the CFI, TLI and RMSEA were used. A CFI over 0.90 is ideal (Bentler \& Bonett, 1980); exceeding 0.95 is an excellent fit (Hu \& Bentler, 1999). Although TLI is generally less than GFI, TLI higher than 0.95 are considered acceptable (Jang et al., 2018). RMSEA value is lower than 0.05 , presenting a good fit, while this value is between 0.05 and 0.08, indicating a moderate fit (Browne \& Cudeck, 1993). Moreover, the mediating roles of three antecedents in the theory of planned behaviour (Ajzen, 1991) on the links between regulatory, normative supports and intention to commercialise inventions were tested using a bootstrapping method (Shrout \& Bolger, 2002; Preacher \& Hayes, 2008) to estimate the direct, indirect and total influences between the constructs.

\subsection{Measures}

Scientists and researchers are required to rate their agreement on the scale of 1 (strongly disagree) to 5 (strongly agree) on six measures related to regulatory and normative dimensions and their cognitive process in commercialising invention and/or research results. All scales are adopted from previous studies and reflect scientists' perceptions, which include regulatory and normative support (Busenitz et al., 2000), attitude towards invention commercialisation, subjective norms, perceived behavioural control and intention to commercialising invention (Liñán \& Chen, 2009). Detailed scales are represented in Table 2. 
Table 2 | Cronbach's alpha and descriptive characteristics of scales

\begin{tabular}{|c|c|c|c|c|}
\hline Code & Items & Skewness & Kurtosis & $\begin{array}{c}\text { Cronbach's } \\
\text { alpha }\end{array}$ \\
\hline $\mathrm{ICl}$ & Intention to commercialise invention & -0.085 & -0.598 & 0.891 \\
\hline ICl1 & I am ready to do anything to commercialise my research result & -0.032 & -0.669 & 0.860 \\
\hline $\mathrm{ICl} 2$ & $\begin{array}{l}\text { My professional goal is to become an innovative entrepreneur/ } \\
\text { an inventor }\end{array}$ & -0.285 & -0.639 & 0.861 \\
\hline $\mathrm{ICl} 3$ & I will make every effort to commercialise my research result & 0.045 & -0.467 & 0.850 \\
\hline ICl4 & $\begin{array}{l}\text { I am determined to commercialise my research results in the } \\
\text { future }\end{array}$ & -0.183 & -0.624 & 0.859 \\
\hline ICI5 & $\begin{array}{l}\text { I have a very seriously through of commercialising research } \\
\text { result }\end{array}$ & -0.018 & -0.092 & 0.913 \\
\hline ICl6 & I have the firm intention to commercialise my research result & -0.192 & -0.523 & 0.882 \\
\hline AIC & Attitude towards invention commercialisation & -0.051 & -0.226 & 0.770 \\
\hline AlC1 & $\begin{array}{l}\text { Being an innovative entrepreneur/ an inventor implies more } \\
\text { advantage than disadvantages to me }\end{array}$ & -0.152 & -0.174 & 0.709 \\
\hline AIC2 & $\begin{array}{l}\text { A career as an innovative entrepreneur/ an inventor is attractive } \\
\text { for me }\end{array}$ & -0.639 & 0.000 & 0.743 \\
\hline AIC3 & $\begin{array}{l}\text { If I had the opportunity and resources, l'd like to start invention } \\
\text { commercialisation }\end{array}$ & -0.075 & -0.367 & 0.685 \\
\hline AIC4 & $\begin{array}{l}\text { Being an innovative entrepreneur/ an inventor would entail } \\
\text { great satisfactions for me }\end{array}$ & 0.032 & -0.569 & 0.683 \\
\hline AIC5 & $\begin{array}{l}\text { Among various options, would rather be an innovative } \\
\text { entrepreneur/ an inventor }\end{array}$ & -0.371 & -0.403 & 0.806 \\
\hline SN & Subjective norms & -0.471 & 0.878 & 0.882 \\
\hline SN1 & $\begin{array}{l}\text { If I decided to commercialise my research result, my closest } \\
\text { family would approve of that decision }\end{array}$ & -0.419 & -0.246 & 0.838 \\
\hline SN2 & $\begin{array}{l}\text { If I decided to commercialise my research result, my closest } \\
\text { friends would approve of that decision }\end{array}$ & -0.582 & 0.593 & 0.704 \\
\hline SN3 & $\begin{array}{l}\text { If I decided to commercialise my research result, my colleagues } \\
\text { would approve of that decision }\end{array}$ & -0.334 & 0.042 & 0.726 \\
\hline PBC & Perceived behaviour control & 0.736 & 1.533 & 0.840 \\
\hline PBC1 & $\begin{array}{l}\text { To start invention commercialisation and keep it working would } \\
\text { be easy for me }\end{array}$ & 0.555 & 0.886 & 0.818 \\
\hline PBC2 & I am prepared to start invention commercialisation & 0.917 & 1.565 & 0.797 \\
\hline PBC3 & $\begin{array}{l}\text { I can control the creation process of commercialising my } \\
\text { research result }\end{array}$ & 0.522 & -0.092 & 0.799 \\
\hline PBC4 & $\begin{array}{l}\text { I know the necessary practical details to commercialise my } \\
\text { research result }\end{array}$ & 0.417 & -0.325 & 0.813 \\
\hline PBC5 & I know how to develop an innovative entrepreneurial project & 0.732 & 0.503 & 0.809 \\
\hline PBC6 & $\begin{array}{l}\text { If I tried to commercialise research result, I would have a high } \\
\text { probability of succeeding }\end{array}$ & 0.040 & -0.263 & 0.843 \\
\hline RS & Regulatory support & -0.332 & 0.878 & 0.736 \\
\hline RS1 & $\begin{array}{l}\text { Government organisations in Vietnam assist scientists with } \\
\text { commercialising their research result }\end{array}$ & -0.390 & -0.246 & 0.609 \\
\hline RS2 & $\begin{array}{l}\text { The government sets aside government contracts for } \\
\text { commercialising research result }\end{array}$ & -0.247 & 0.593 & 0.700 \\
\hline RS3 & $\begin{array}{l}\text { Local and national governments have special support available } \\
\text { for scientists who want to commercialising their research } \\
\text { results }\end{array}$ & -0.058 & 0.042 & 0.674 \\
\hline
\end{tabular}




\begin{tabular}{|c|c|c|c|c|}
\hline RS4 & $\begin{array}{l}\text { The government sponsors organizations that help new } \\
\text { innovative business/ invention develop }\end{array}$ & -0.282 & 1.533 & 0.674 \\
\hline RS5 & $\begin{array}{l}\text { Even after failing in an earlier commercialisation period, the } \\
\text { government assists scientists in starting again }\end{array}$ & -0.306 & 0.886 & 0.715 \\
\hline NS & Normative supports & -0.289 & 0.671 & 0.835 \\
\hline NS1 & $\begin{array}{l}\text { Turning research result into commercialisation/business is an } \\
\text { admired career path in Vietnam }\end{array}$ & 0.155 & 0.527 & 0.809 \\
\hline NS2 & $\begin{array}{l}\text { In Vietnam, innovative and creative thinking is viewed as the } \\
\text { route to success }\end{array}$ & 0.036 & -0.386 & 0.797 \\
\hline NS3 & Innovative entrepreneurs/inventors are admired in Vietnam & -0.492 & 0.045 & 0.781 \\
\hline NS4 & $\begin{array}{l}\text { People in Vietnam tend to greatly admire those who } \\
\text { commercialise their research results }\end{array}$ & 0.160 & 0.306 & 0.777 \\
\hline
\end{tabular}

Note: $\mathrm{N}=255$

Source: own calculations

\section{Results}

\subsection{Exploratory Factor Analysis}

After the internal consistency reliability of each construct being examined by Cronbach's alpha, all satisfactory scales and items are then used in the exploratory factor analysis. The initial results reveal that $\mathrm{KMO}=0.892$, Sig. (Barlett's test $)<0.001$, Initial Eigenvalues $=$ $66.867>50 \%$. Nevertheless, factor loading of ICI5 (0.343), AIC2 (0.441) and PBC6 (0.440) $<0.5$ and loaded at different factor groups. Therefore, we decided to remove these items from the initial scales before conducting confirmatory factor analysis (Nunnally \& Bernstein, 1994). The final result of exploratory factor analysis (EFA) was revealed in Table 3.

Table 3 | Exploratory Factor Analysis (EFA)

\begin{tabular}{|c|c|c|c|c|c|c|}
\hline \multirow[b]{2}{*}{ Items } & \multicolumn{6}{|c|}{ Rotated Factor Loadings } \\
\hline & $\begin{array}{l}\text { Intention to } \\
\text { commercialise } \\
\text { invention } \\
\text { (ICI) }\end{array}$ & $\begin{array}{c}\text { Perceived } \\
\text { behavioural } \\
\text { control } \\
\text { (PBC) }\end{array}$ & $\begin{array}{l}\text { Normative } \\
\text { support } \\
\text { (NS) }\end{array}$ & $\begin{array}{l}\text { Subjective } \\
\text { norms } \\
\text { (SN) }\end{array}$ & $\begin{array}{c}\text { Attitude towards } \\
\text { invention } \\
\text { commercialisation } \\
\text { (AIC) }\end{array}$ & $\begin{array}{c}\text { Regulatory } \\
\text { support (RS) }\end{array}$ \\
\hline $\mathrm{ICl} 3$ & 0.864 & & & & & \\
\hline $\mathrm{ICl} 2$ & 0.844 & & & & & \\
\hline $\mathrm{ICl1}$ & 0.801 & & & & & \\
\hline $\mathrm{ICl} 4$ & 0.785 & & & & & \\
\hline $\mathrm{ICl} 6$ & 0.645 & & & & & \\
\hline PBC2 & & 0.806 & & & & \\
\hline PBC3 & & 0.753 & & & & \\
\hline PBC1 & & 0.724 & & & & \\
\hline PBC4 & & 0.648 & & & & \\
\hline PBC5 & & 0.531 & & & & \\
\hline NS2 & & & 0.769 & & & \\
\hline
\end{tabular}


Note: $\mathrm{N}=255$

Source: own calculations

\subsection{Measurement model}

Research results illustrated some unsatisfactory model fitness in the Initial measurement model. Although CMIN/DF $=1.743 ; \mathrm{CFI}=0.939>0.9 ; \mathrm{TLI}=0.929>0.9 ;$ but $\mathrm{RMSEA}=0.054$ $>0.5$ and $\mathrm{GFI}=0.878<0.9$. Also, the standarized regression weights of RS1 (0.493), RS2 $(0.371)$ and AIC5 $(0.304)<0.5$. Thus, we decided to extract these items from measurement model and perform again. The final measurement model showed that the fit indices revealed the model fit data reasonably well $(\mathrm{CMIN} / \mathrm{DF}=1.560<2$; GFI $=0.903>0.9$; $\mathrm{CFI}=0.963>0.9 ; \mathrm{TLI}=0.955>0.9$; and RMSEA = $0.047<0.5)$ (Browne \& Cudeck, 1993; $\mathrm{Hu} \&$ Bentler, 1999). Moreover, the standardized regression weights of all items are higher than 0.5 (Table 5). 


\begin{tabular}{lcccccccc}
\hline & CR & AVE & AIC & ICI & PBC & NS & SN & RS \\
\hline $\begin{array}{l}\text { Attitude towards invention } \\
\text { commercialisation (AIC) }\end{array}$ & 0.819 & 0.606 & $\mathbf{0 . 7 7 8}$ & & & & & \\
$\begin{array}{l}\text { Intention to commercialise } \\
\text { inventions (ICI) }\end{array}$ & 0.915 & 0.686 & 0.661 & $\mathbf{0 . 8 2 8}$ & & & & \\
$\begin{array}{l}\text { Perceived behavioral } \\
\text { control (PBC) }\end{array}$ & 0.851 & 0.534 & 0.440 & 0.593 & $\mathbf{0 . 7 3 1}$ & & & \\
Normative support (NS) & 0.837 & 0.562 & 0.528 & 0.591 & 0.739 & $\mathbf{0 . 7 5 0}$ & & \\
$\begin{array}{l}\text { Subjective norms (SN) } \\
\text { Regulatory support (RS) }\end{array}$ & 0.832 & 0.627 & 0.325 & 0.296 & 0.290 & 0.274 & $\mathbf{0 . 7 9 2}$ & \\
\hline
\end{tabular}

Note: $\mathrm{N}=255$; AVE: Average variance extracted, CR: Composite reliability.

Source: own calculations

Both average variances extracted (AVE), composite reliability (CR) (Anderson \& Gerbing, 1988) were tested to show the reliability, convergent validity and discriminant validity of constructs (Hair et al., 2010). As indicated in Table 4, CR values for all variables were noticed to be higher than 0.60 , the CR value of regulatory support (RS) was the lowest $(0.691)$. Also, almost AVE values were within their recommended level with a value higher than 0.5 . Although the AVE value of regulatory support (RS) only reached 0.431 , however, Ertz et al. (2016) argued that this value could be acceptable.

Table 5 | Standardised regression weights

\begin{tabular}{lll}
\hline Constructs & Items & Estimate \\
\hline Intention to commercialise invention (ICI) & ICI3 & 0.939 \\
& ICl2 & 0.873 \\
Perceived behavior control (PBC) & ICl4 & 0.786 \\
& ICl6 & 0.884 \\
& PBC2 & 0.620 \\
& PBC3 & 0.764 \\
& PBC1 & 0.784 \\
Normative support (NS) & PBC4 & 0.644 \\
& PBC5 & 0.663 \\
& NS2 & 0.787 \\
& NS3 & 0.714 \\
& NS4 & 0.768 \\
& NS1 & 0.795 \\
\end{tabular}




\begin{tabular}{lll} 
& SN3 & 0.805 \\
Subjective norms (SN) & SN2 & 0.897 \\
& SN1 & 0.654 \\
& AIC3 & 0.726 \\
$\begin{array}{lll}\text { Attitude towards invention commercialisation } \\
\text { (AIC) }\end{array}$ & AIC4 & 0.914 \\
& AIC1 & 0.675 \\
& RS4 & 0.673 \\
Regulatory support (RS) & RS5 & 0.535 \\
& RS3 & 0.744 \\
\hline
\end{tabular}

Source: own calculations

\subsection{Structural model}

At the second stage, the structural model was tested to validate the conceptual framework and estimate the relationships in the research model.

Figure 2 | Structural model (Standardised estimates)

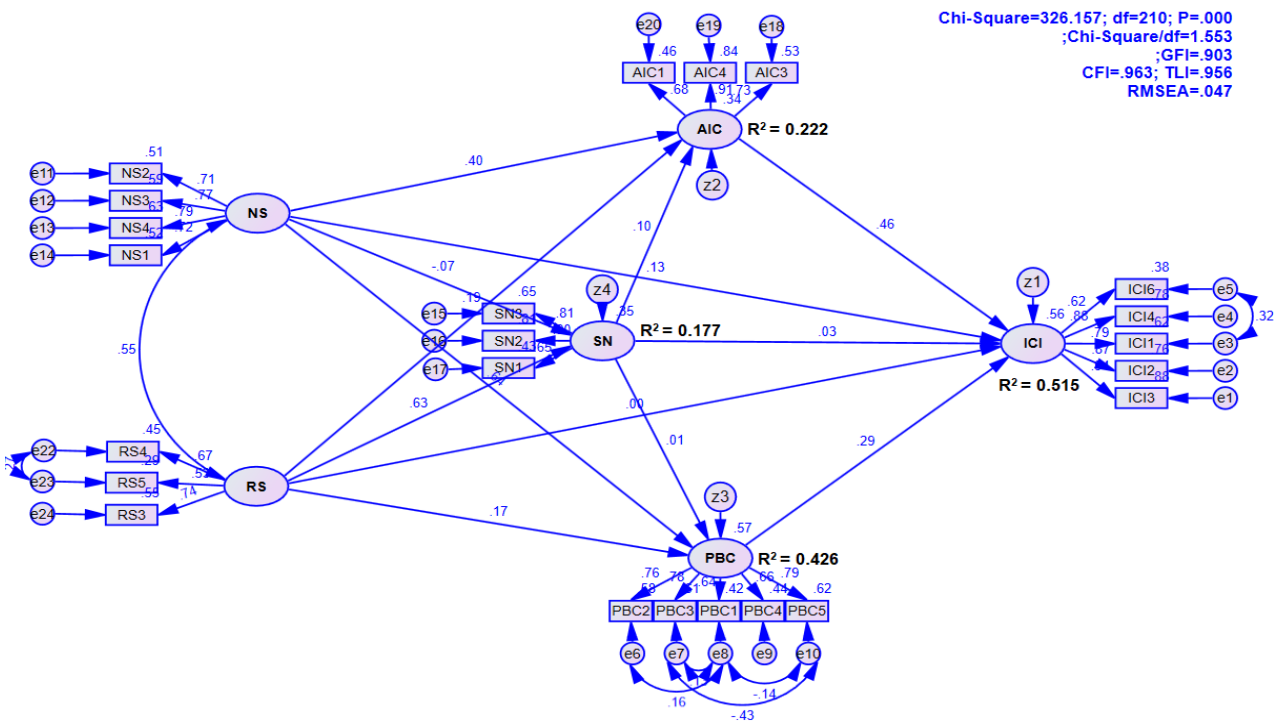

Note: $\mathrm{N}=255$

Source: own calculations

Similar to the measurement model, the structural fully fitted the observed data as its fit indices were shown within the suggested level as follows: CMIN/DF $=1.553<2$; GFI= $0.903>0.9$; $\mathrm{CFI}=0.963>0.5 ; \mathrm{TLI}=0.956>0.9$; and RMSEA $=0.047<0.5$ (Browne \& Cudeck, 1993; Hu $\&$ Bentler, 1999). Figure 2 revealed that a good predictive validity was reached by the 
conceptual framework as well. Particularly, the variances (R-square) of subjective norms (SN), attitude towards invention commercialisation (AIC), perceived behaviour control (PBC) and intention to commercialise invention accounted for $0.177,0.222,0.426$ and 0.515 , respectively. Also, as illustrated in Table 6 , all values yielded in terms of variance inflation factors (VIF) confirms that because all VIF values were represented to be less than 4 (the maximal value is 1.891), thus, there is no concern about multi-collinearity between independent and dependent variables within the proposed model (Hair et al., 2010). In other words, the model estimations do not have a multi-collinearity bias.

Table 6 | Standardised estimates

\begin{tabular}{|c|c|c|c|c|c|c|c|c|c|}
\hline Hypothesis & & & aths & Estimate & SE. & CR. & $\begin{array}{c}\text { P. } \\
\text { value }\end{array}$ & VIF & $\begin{array}{c}\text { Significan- } \\
\text { ce } \\
\text { [YES/NO] }\end{array}$ \\
\hline H1a & $\begin{array}{l}\text { Attitude towards } \\
\text { invention } \\
\text { commercialisation }\end{array}$ & $\rightarrow$ & $\begin{array}{l}\text { Intention to commercialise } \\
\text { invention }\end{array}$ & 0.458 & 0.107 & 6.440 & $\star \star *$ & 1.298 & Yes \\
\hline H1b & Subjective norms & $\rightarrow$ & $\begin{array}{l}\text { Intention to commercialise } \\
\text { invention }\end{array}$ & 0.030 & 0.102 & 0.422 & 0.673 & 1.251 & No \\
\hline H1c & $\begin{array}{l}\text { Perceived } \\
\text { behaviour control }\end{array}$ & $\rightarrow$ & $\begin{array}{l}\text { Intention to commercialise } \\
\text { invention }\end{array}$ & 0.293 & 0.139 & 3.300 & $* * *$ & 1.760 & Yes \\
\hline $\mathrm{H} 2 \mathrm{a}$ & Subjective norms & $\rightarrow$ & $\begin{array}{l}\text { Attitude towards invention } \\
\text { commercialisation }\end{array}$ & 0.104 & 0.062 & 2.491 & 0.013 & 1.215 & Yes \\
\hline $\mathrm{H} 2 \mathrm{~b}$ & Subjective norms & $\rightarrow$ & Perceived behaviour control & 0.013 & 0.070 & 0.174 & 0.862 & 1.215 & No \\
\hline H3a & Regulatory support & $\rightarrow$ & $\begin{array}{l}\text { Attitude towards invention } \\
\text { commercialisation }\end{array}$ & 0.190 & 0.061 & 2.492 & 0.013 & 1.475 & Yes \\
\hline H3b & Regulatory support & $\rightarrow$ & Subjective norms & 0.632 & 0.155 & 5.251 & *** & 1.252 & Yes \\
\hline $\mathrm{H} 3 \mathrm{c}$ & Regulatory support & $\rightarrow$ & Perceived behaviour control & 0.170 & 0.081 & 1.283 & 0.032 & 1.430 & Yes \\
\hline H3d & Regulatory support & $\rightarrow$ & $\begin{array}{l}\text { Intention to commercialise } \\
\text { invention }\end{array}$ & -0.005 & 0.182 & -0.048 & 0.962 & 1.475 & No \\
\hline $\mathrm{H} 4 \mathrm{a}$ & Normative support & $\rightarrow$ & $\begin{array}{l}\text { Attitude towards invention } \\
\text { commercialisation }\end{array}$ & 0.339 & 0.095 & 4.286 & $\star \star * *$ & 1.259 & Yes \\
\hline $\mathrm{H} 4 \mathrm{~b}$ & Normative support & $\rightarrow$ & Subjective norms & -0.075 & 0.100 & -0.795 & 0.427 & 1.252 & No \\
\hline $\mathrm{H} 4 \mathrm{c}$ & Normative support & $\rightarrow$ & Perceived behaviour control & 0.643 & 0.090 & 6.955 & *** & 1.259 & Yes \\
\hline H4d & Normative support & $\rightarrow$ & $\begin{array}{l}\text { Intention to commercialise } \\
\text { invention }\end{array}$ & 0.127 & 0.082 & 2.456 & 0.014 & 1.891 & Yes \\
\hline
\end{tabular}

Note: $\mathrm{N}=255$

Source: own calculations

Table 6 also represented that intention to commercialise invention is positively affected by attitude towards invention commercialisation $(\beta=0.458 ; p$-value $<0.001)$, perceived behavioural control $(\beta=0.293$; $p$-value $<0.001)$, and normative support $(\beta=0.127$; $p$-value $<0.05)$. Yet, results also confirmed that regulatory support and subjective norms are not related to scientists' intention to commercialise invention ( $p$-value $=0.962$ and $0.673>0.05$, respectively). Thus, $\mathrm{H} 1 \mathrm{a}, \mathrm{H} 1 \mathrm{c}$ and $\mathrm{H} 4 \mathrm{~d}$ are supported whereas $\mathrm{H} 1 \mathrm{~b}$, and $\mathrm{H} 3 \mathrm{~d}$ are not supported. Moreover, subjective norms are positively influenced by regulatory support ( $\beta$ $=0.632 ; p$-value $<0.001)$ but not by normative support ( $p$-value $=0.427>0.05)(\mathrm{H} 3 \mathrm{~b}$ is supported, $\mathrm{H} 4 \mathrm{~b}$ is not supported). Also, attitude towards invention commercialisation are positively affected by subjective norms $(\beta=0.104 ; p$-value $=0.013<0.05)$, regulatory support $(\beta=0.190 ; p$-value $=0.013<0.05)$ and normative norms $(\beta=0.339 ; p$-value < 0.001). Therefore, $\mathrm{H} 2 \mathrm{a}, \mathrm{H} 3 \mathrm{a}$ and $\mathrm{H} 4 \mathrm{a}$ are supported. In addition, perceived behaviour control is positively related to normative supports $(\beta=0.643 ; p$-value $<0.001)$ and regulatory supports $(\beta=0.170 ; p$-value $=0.032<0.05)$ but is not affected by subjective norms $(p$-value $=0.108>0.05)$. However, the linkage between subjective norms and perceived behavioural control is not significant ( $p$-value $=0.862>0.05$ ), so, $\mathrm{H} 3 \mathrm{c}$ and $\mathrm{H} 4 \mathrm{c}$ are supported whereas $\mathrm{H} 2 \mathrm{~b}$ and $\mathrm{H} 3 \mathrm{c}$ are not. 
Mediation analysis was utilised to estimate how much effect mediation role is between normative, regulatory supports and intention to commercialise invention among scientists. Cheung \& Lau (2008) argue that bootstrapping confidence interval estimates should be employed to examine the mediation role. This study used 1000 bootstrap samples with a confident degree of $90 \%$.

Table 7 | Bootstrapping results

\begin{tabular}{|c|c|c|c|c|c|c|c|c|c|c|}
\hline \multirow[t]{2}{*}{ Paths } & \multicolumn{2}{|c|}{$\begin{array}{l}\text { Standardised direct } \\
\text { effects }\end{array}$} & \multicolumn{2}{|c|}{$\begin{array}{l}\text { Standardised } \\
\text { indirect effects } \\
\text { (AIC mediator) }\end{array}$} & \multicolumn{2}{|c|}{$\begin{array}{l}\text { Standardised } \\
\text { indirect effects } \\
\text { (SN mediator) }\end{array}$} & \multicolumn{2}{|c|}{$\begin{array}{l}\text { Standardised } \\
\text { indirect effects } \\
\text { (PBC mediator) }\end{array}$} & \multicolumn{2}{|c|}{$\begin{array}{l}\text { Standardised } \\
\text { total effects }\end{array}$} \\
\hline & Estimate & $\begin{array}{c}\mathrm{P}- \\
\text { value }\end{array}$ & Estimate & $\begin{array}{c}\mathrm{P}- \\
\text { value }\end{array}$ & Estimate & P-value & Estimate & $\begin{array}{c}\mathrm{P}- \\
\text { value }\end{array}$ & Estimate & $\begin{array}{c}\mathrm{P} \text { - } \\
\text { value }\end{array}$ \\
\hline $\begin{array}{l}\text { Normative support } \rightarrow \\
\text { Subjective norms }\end{array}$ & -0.075 & 0.427 & & & & & & & -0.075 & 0.427 \\
\hline $\begin{array}{l}\text { Regulatory support } \rightarrow \\
\text { Subjective norms } \\
\text { Normative }\end{array}$ & 0.632 & 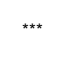 & & & & & & & 0.632 & $\star \star \star \star$ \\
\hline $\begin{array}{l}\text { support } \rightarrow \text { Attitude } \\
\text { towards invention } \\
\text { commercialisation }\end{array}$ & 0.339 & 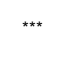 & & & & & & & 0.339 & 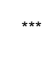 \\
\hline $\begin{array}{l}\text { Subjective norms } \\
\rightarrow \text { Attitude towards } \\
\text { invention } \\
\text { commercialisation }\end{array}$ & 0.104 & 0.013 & & & & & & & 0.104 & 0.013 \\
\hline $\begin{array}{l}\text { Subjective } \\
\text { norms } \rightarrow \text { Perceived } \\
\text { behavioural control }\end{array}$ & 0.013 & 0.862 & & & & & & & 0.013 & 0.862 \\
\hline $\begin{array}{l}\text { Regulatory support } \\
\rightarrow \text { Perceived } \\
\text { behavioural control } \\
\text { Normative }\end{array}$ & 0.170 & 0.032 & & & & & & & 0.217 & 0.031 \\
\hline $\begin{array}{l}\text { support } \rightarrow \text { Perceived } \\
\text { behavioural control } \\
\text { Regulatory }\end{array}$ & 0.643 & 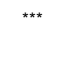 & & & & & & & 0.643 & 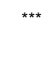 \\
\hline $\begin{array}{l}\text { support } \rightarrow \text { Attitude } \\
\text { towards invention } \\
\text { commercialisation }\end{array}$ & 0.190 & 0.013 & & & 0.535 & 0.002 & & & 0.725 & 0.012 \\
\hline $\begin{array}{l}\text { Normative support } \\
\rightarrow \text { Intention to } \\
\text { commercialise } \\
\text { invention }\end{array}$ & 0.127 & 0.014 & 0.291 & 0.004 & & & 0.267 & 0.001 & 0.685 & 0.002 \\
\hline $\begin{array}{l}\text { Attitude towards } \\
\text { invention } \\
\text { commercialisation } \rightarrow \\
\text { Intention to } \\
\text { commercialise } \\
\text { invention }\end{array}$ & 0.458 & $\star \star \star \star ~$ & & & & & & & 0.458 & $\star \star \star$ \\
\hline $\begin{array}{l}\text { Perceived behavioural } \\
\text { control } \rightarrow \text { Intention to } \\
\text { commercialise } \\
\text { invention }\end{array}$ & 0.293 & $\star \star \star$ & & & & & & & 0.293 & $\star \star \star \star$ \\
\hline $\begin{array}{l}\text { Subjective norms } \\
\rightarrow \text { Intention to } \\
\text { commercialise } \\
\text { invention }\end{array}$ & 0.030 & 0.673 & 0.202 & 0.001 & & & & & 0.202 & 0.001 \\
\hline $\begin{array}{l}\text { Regulatory } \\
\text { support } \rightarrow \text { Intention to } \\
\text { commercialise } \\
\text { invention }\end{array}$ & -0.005 & 0.962 & 0.257 & 0.002 & & & 0.253 & 0.001 & 0.510 & 0.002 \\
\hline
\end{tabular}

Note: $\mathrm{N}=255 ;{ }^{* * *} \mathrm{p}<0.001$, AIC: Attitude towards invention commercialisation, SN: Subjective norms, PBC: Perceived behavioural control

Source: own calculation

Table 7 revealed that only attitude towards invention commercialisation played the full mediator in the linkage between subjective norms and intention to commercialise invention among Vietnamese scientists $\left(\beta_{\text {indirect effect }}=0.202\right.$; $p$-value $=0.001<0.01$ ), while perceived behavioural control did not mediate this relationship because subjective norms did not affect directly on perceived behavioural control and intention to commercialise invention ( $\mathrm{H} 5 \mathrm{c}$ is supported and $\mathrm{H} 7 \mathrm{c}$ is not supported). It means that although subjective norms do not affect 
directly, it had strong effects on scientists' intention to commercialise invention via attitude towards invention commercialisation. The standardised mediated influence of subjective norms on intention to commercialise invention via attitude towards invention commercialisation is $\mathbf{0 . 2 0 2}$. That was, due to the mediated impact of subjective norms on intention to commercialise the invention, when subjective norm go up by 1 standard deviation, intention to commercialise invention goes up by 0.202 standard deviation.

The correlation between normative norms and scientists' intention to commercialise invention was partially mediated by attitude towards invention commercialisation ( $\beta_{\text {indirect effect }}=0.291$;

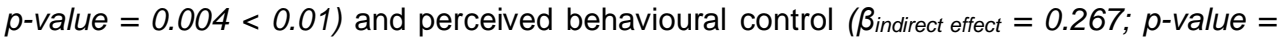
$0.001<0.01$ ), but not be mediated by subjective norms ( $\mathrm{H} 5 \mathrm{~b}$ and H7b was supported, H6b was not supported). In addition, perceived behavioural control ( $\beta_{\text {indirect effect }}=0.253 ; p$-value $=$ $0.001<0.01)$ and attitude towards invention commercialisation $\left(\beta_{\text {indirect effect }}=0.257 ; p\right.$-value $=0.002<0.01$ ) were seen as full mediators in the link between regulatory support and intention to commercialise invention among Vietnamese scientists whereas the mediating role of subjective norms was not significant ( $\mathrm{H} 6 \mathrm{a}$ was not supported, $\mathrm{H} 5 \mathrm{a}$ and $\mathrm{H} 7 \mathrm{a}$ were supported).

\section{Discussion and Conclusions}

Scholars are striving to understand more why an individual has an intention and decision to become an entrepreneur (Burger \& Blažková, 2020; Dvouletý, 2017; Holienka et al., 2017; Krueger et al., 2000; Liñán \& Chen, 2009). However, researches on academic entrepreneurship or invention commercialisation, especially in exploring the role of contextual factors in shaping intention to commercialise invention among scientists, are rather sparse (Nguyen et al., 2018; Perkmann et al., 2013). Recently, entrepreneurship literature, therefore, has overlooked scholarly efforts to better understand how country institutional profiles (Busenitz et al., 2000) relate to scientists' intention and actual behaviour to commercialise their invention (Aldridge \& Audretscg, 2010; Nguyen et al., 2018) or licensing patters (Wu et al., 2015). In this study, we explicitly challenged prior entrepreneurship studies that investigate the linkages between contextual factors and scientists' intention to commercialise invention based on the conceptual framework that combined the lens of country institutional profile (Busenitz et al., 2000) and the theory of planned behaviour (Ajzen, 1991). We argue that contextual factors, including normative and regulatory supports, can directly influence scientists' intention to commercialise their invention, and those linkages are also mediated by three antecedents of the theory of planned behaviours (Ajzen, 1991). To our knowledge, ours can be the first research to build and test these relationships.

Our findings have some important contributions to entrepreneurship literature more generally. Firstly, our study presented that subjective norms were not directly related to intention to commercialise invention among scientists, but this relationship was mediated by the attitude towards invention commercialisation. There was similar to many prior studies that applied the theory of planned behaviour in entrepreneurship studies (e.g. Liñán, 2008; Miranda et al., 2017; Tsai et al., 2016). Secondly, regulatory support, although it did not have a direct effect, it had indirect impacts on the intention to commercialise invention throughout attitude towards invention commercialisation and perceived behavioural controls. In other words, both attitude towards invention commercialisation and perceived behavioural controls fully mediated the link between regulatory support and intention to commercialise the invention. Moreover, 
normative support, that reflects the level of which a nation' citizens admire and respect entrepreneurial, innovative and creative activities, not only directly influence, but it also has a strong and mediated effect on scientists' intention to commercialise invention via attitude towards invention commercialisation and perceived behavioural control. The direct effect of regulatory and normative dimensions on start-up intention (Schillo et al., 2016) or entrepreneurial innovation (Arabiyat et al., 2019) was confirmed (Bruton et al., 2010; Dau \& Cuervo-Cazurra, 2014; Estrin et al., 2011; Smallbone \& Welter, 2012). Yet, the mediated impacts of regulatory and normative dimensions on the intention to commercialise invention among scientists throughout three antecedents in the theory of planned behaviour are not adequately interested. Finally, our findings showed that country's institutional profile, including regulatory and normative supports, were positively internalised into scientists' cognitive process of entrepreneurship that derived from the attitude towards invention commercialisation, subjective norms and perceived behavioural control.

Besides the theoretical contributions, our study also contributes to practical implications for policymakers and researchers. Our study indicates the role of the regulatory supports in promoting academic entrepreneurship or boosting scientists' invention or their research results commercialisation. Thus, through some tools such as matchmaking, technology market, developing technology intermediators, financial supports, the government can boost entrepreneurial spirit and promote commercialisation (Nguyen et al., 2018). For researchers, also can find an effective and profitable approach to commercialise their research results and create values for the society and market. In addition, this study is seen as a pioneer in empirically exploring the role of country institutional profile in shaping scientists' cognitive process of commercialising research results in an emerging economy.

Analogously to Vietnam, since the early 1990s when Central European Countries stepped on a transitional path towards globally integrated market economics and the reforming of their domestic economies commenced (Kondratiuk-Nierodzińska, 2016). In other words, Like Vietnam, Central European Countries have transitioned from centrally-planned to marketbased economies. With various degrees, these emerging economies committed to developing their market mechanisms throughout encouraging private business, stabilising the domestic economies and liberalisation (Ённи Р. \& Манолова, 2013). Emerging economies are often correlated with the growth of a vibrant entrepreneur class. The development of private entrepreneurial activities accelerated the transitional process from state-centred economies to competitive markets (Manev \& Manolova, 2010). Thus, entrepreneurship or/and academics' invention commercialisation also play an important role in the development of national economies and well-being of Central Europe (Fedirko, 2014; Riviezzo et al., 2019; Wisła \& Sierotowicz, 2015). Generally, academics are found to have a significant contribution to the invention commercialisation or patenting activities in European countries, especially in science-based innovation and technologies, including Pharmaceuticals \& Biotechnology, Chemicals \& Materials, Measurement \& Scientific Instruments, Electrical Engineering \& Electronics (Lissoni, 2012). Radosevic (2017, p.1) state that "the future growth of Central and Eastern European (CEE) depends on upgrading technology, exporting, and coupling domestic technology efforts while improving their position in global value chains", however, current policies in this region are still not geared to these missions while the availability of big opportunities to obtain financial supports in the form of EU structural funds (Kondratiuk-Nierodzińska, 2016) while Dvouletý (2018, p. 97) also argue that "macroeconomic institutional and economic environment influences the most of the 
entities (both established and early-stage enterprises) present in the economy in a similar direction". Scholars agreed that almost emerging economies had endured from a lack of developed market institutions (Nguyen et al., 2020), such as the lack of effective contract enforcement, the lack of clear property right or the transparent market information deters efforts of entrepreneurs to be innovative (Smallbone et al., 2014). Thus, governments of Central European economies should have more appropriate policies to sufficiently promote technological innovation, the enhancement of innovative ecosystem and fostering academic entrepreneurship as well. As a result, the findings of our study can also serve as a useful reference for policymakers and researchers in other emerging countries in the Central European region in order to promote scientists' invention commercialisation.

However, we are aware of some limitations in our study as follows. Firstly, our study focused on the invention commercialisation of a relatively sample of scientists and researchers at Vietnamese universities and institutes, increasing the question of the study's external generalisability. To tackle this problem, we employed the approach of stratified random sampling, so the confidentiality and representativity of the sample were secure. Further researches can utilise the other method or raise the sample size to increase the generalisability of the sample. Another limitation was that the measures of regulatory and normative supports only reflected the perceptions of regulatory and normative supports than directly the actual supports. Thus, further studies can employ other measures which directly refer to actual regulatory and normative supports. In addition, further studies should include the cognitive dimension in the concept of country institutional profiles to reflect the knowledge and skills possessed by scientists in a nation pertaining to starting and operating a new business venture. Also, further research can extend the research model by adding other environmental factors, such as perceived educational supports, perceived corruption, and social capital, or employ other theories to contribute more to entrepreneurship literature.

\section{Acknowledgement}

The authors would like to express sincere thanks to scientists and researchers for participating in the survey. This research is funded by National Economics University, Hanoi, Vietnam, under No. 339/QD-DHKTQD.

\section{References}

Akanbi, S. T. (2013). Familial factors, personality traits and self-efficacy as determinants of entrepreneurial intention among vocational based college of education students in OYA state, Nigeria. The African Symposium: An Online Journal of the African Educational Research Network, 13(2), 66-76.

Alvarez, C., \& Urbano, D. (2012). Cultural-cognitive dimension and entrepreneurial activity: A crosscountry study. Revista de Estudios Sociales, 44, 146-157.

Anderson, J. C., \& Gerbing, D. W. (1988). Structural equation modelling in practice: A review and recommended two-step approach. Psychological Bulletin, 103(3), 411-423.

Antoncic, B., \& Prodan, I. (2008). Alliances, technological entrepreneurship and firm performance: Testing a model on manufacturing firms. Technovation, 28(5), 257-265.

Aldridge, T. T., \& Audrestsch, D. B. (2010). Does policy influence the commercialisation route? Evidence from National Institutes of Health funded scientists. Research Policy, 39(5), 583-588. 
Aldridge, T. T., \& Audrestsch, D. (2011). The Bayh-Dole act and scientist entrepreneurship. Research Policy, 40(8), 1058-1067.

Aldridge, T.T. \& Audrestsch, D., Desai, S., \& Nadella, V. (2014). Scientist entrepreneurship across scientific fields. Journal of Technology Transfer, 39, 819-835.

Alshumaimri, A., Aldridge, T., \& Audretsch, D. B. (2012). Scientist entrepreneurship in Saudi Arabia. The Journal of Technology Transfer, 37(5), 897-905.

Ajzen, I (1987). Attitudes, traits, and actions: Dispositional prediction of behavior in social psychology. Advances in Experimental Social Psychology, 20, 1-63.

Ajzen, I. (1991). The theory of planned behavior. Organisational Behavior and Human Decision Process, $50(2), 1-63,179-211$.

Arabiyat, T., Mdanat, M., Haffar, M. et al. (2019) The Influence of Institutional and Conductive Aspects on Entrepreneurial Innovation: Evidence from GEM Data. Journal of Enterprise Information Management, 32(3), 366-389.

Autio, E., H. Keeley, R., Klofsten, M., Parker, G. C., \& Hay, M. (2001). Entrepreneurial intent among students in Scandinavia and in the USA. Enterprise and Innovation Management Studies, 2, 145-160. https://doi.org/10.1080/14632440110094632.

Bandura, A. (1977). Social Learning Theory, Prentice Hall, Englewood Cliffs, NJ.

Baughn, C. C., Cao, J. S. R., Le, L. T. M., Lim, V. A., \& Neupert, K. E. (2006). Normative, Social and Cognitive predictors of entrepreneurial interest in China, Vietnam and the Philippines. Journal of Development Entrepreneurship, 11(1), 57-77.

Baughn, C., Lim, V. A., Le, L. T. M., Neupert, K.E., \& Woods, L. S. (2004). Identification of entrepreneurial opportunities in Asia. Opportunity Identification and Entrepreneurial Behavior, J Butler (ed.). Greenwich, Conn: Information Age Publishing, 191-218.

Bercovitz, J., \& Feldman, M. (2008). Academic entrepreneurs: Organisational change at the individual level. Organization Science, 19(1), 69-89.

Bentler, P. M., \& Bonett, D. G. (1980). Significance tests and goodness of fit in the analysis of covariance structures. Psychological Bulletin, 88(3), 588-606. https://doi.org/10.1037/0033-2909.88.3.588.

Bird, B. (1998). Implementing entrepreneurial ideas: The case for intention. Academy of Management Review, 13(3), 442-453.

Bird, B., \& Brush, C. G. (2002). A gender perspective on organisational creation. Entrepreneurship Theory and Practice, 26 (3), 41-65.

Bird, B., \& Jeline, M. (1988). The operation of entrepreneurial intentions. Entrepreneurship Theory and Practice, 13(2), 21-29.

Boden Jr., R. J., \& Nucci, A. (2000). On the survival prospects of men's and women's new business ventures. Journal of Business Venturing, 15(4), 347-362.

Burger, L., \& Blažková, I. (2020). Internal Determinants Promoting Corporate Entrepreneurship in Established Organisations: A Systematic Literature Review. Central European Business Review, 9(2), 19-45. https://doi.org/10.18267/j.cebr.233.

Byrne, B. (2010). Structural equation modeling with AMOS: Basic concepts, applications and programming (6th ed.). New York, USA: Taylor \& Francis Group.

Bruton, G., \& Ahlstrom, D. (2003). An Institutional View of China's Venture Capital Industry. Explaining the Differences between China and the West. Journal of Business Venturing, 18(2), 233-259. 
Bruton, G. D., Ahlstrom, D., \& Oboloj, K. (2008). Entrepreneurship in emerging economies: where are we today and where should the research go in the future. Entrepreneurship Theory and Practice, $32(1), 1-14$.

Bruton, G. D., Ahlstrom, D., \& Li, H. L. (2010). Institutional theory and entrepreneurship: where are we now and where do we need to move in the future? Entrepreneurship Theory and Practice, 34(3), 421-440. https://doi.org/10.1111/j.1540-6520.2010.00390.x.

Busenitz, L. Gomez, C. \& Spencer, J. (2000). Country institutional profile: Unlocking entrepreneurial phenomena. Academy of Management Journal, 45(5), 994-1003.

Camelo-Ordaz, C., Dianez-Gonzalez, J. D., \& Ruiz-Navarro, J. (2016). The influence of gender on entrepreneurial intention. The mediating role of perceptual factors. Business Research Quartely, 19, 261-277.

Cheung, F. W., \& Lau, R.S. (2008). Testing mediation and suppression effect of latent variables: Bootstrapping with structural equation models. Organizational Research Methods, 11(2), 296-325.

Chiles, T. H., Bluedorn, A. C., \& Gupta, V. K. (2007). Beyond creative destruction and entrepreneurial discovery: a radical Austrian approach to entrepreneurship. Organisation Studies, 28(4), 467-493.

Chowdhury, F., Audretsch, DB, \& Belitski, M. (2019). Institutions and Entrepreneurship Quality. Entrepreneurship Theory and Practice, 43(1), 51-81.

Cook, C., Heath, F., \& Thompson, R. L. (2000). A meta-analysis of response rates in web- or internetbased surveys. Educational and Psychological Measurement, 60(6), 821-836.

Davidsson, P. (1995). Culture, structure and regional levels of entrepreneurship. Entrepreneurship and Regional Development, 7(1), 41-62.

Dau, L. A., \& Cuervo-Cazurra, A. (2014). To formalise or not to formalise: entrepreneurship and promarket institutions. Journal of Business Venturing, 29(5), 668-686.

Dechenaux, E., Thursby, J., \& Thursby, M. (2011). Inventor moral hazard in university licensing: The role of contracts. Research Policy, 40(1), 94-104.

Douhan, R., \& Henrekson, M. (2010). Entrepreneurship and second-best institutions: Going beyond Baumol's typology. Journal of Evolutionary Economics, 20(4), 629-643.

Dvouletý, O. (2017). What is the Relationship between Entrepreneurship and Unemployment in Visegrad Countries? Central European Business Review, 6(2), 42-53. https://doi.org/10.18267/j.cebr.179.

Dvouletý, O. (2018). How to analyse determinants of entrepreneurship and self-employment at the country level? A methodological contribution. Journak of Business Venturing Insights, 9, 92-99. https://doi.org/10.1016/j.jbvi.2018.03.002.

Elston, J., \& Audrestsch, D. B. (2010). Risk attitudes, wealth and sources of entrepreneurial start-up capital. Journal of Economic Behavior \& Organization, 76(1), 82-89.

Ertz, M., Karakas, F., \& Sarigöllü, E. (2016). Exploring pro-environmental behaviors of consumers: An analysis of contextual factors, attitude, and behaviors. Journal of Business Research, 69, 39713980.

Ённи Р. Б., Манолова Т. С. (2013). Institutional context for entrepreneurship in emerging economies: a nine-country comparison of university students' perceptions // Современная конкуренция. 2013. №6 (42). URL: https://cyberleninka.ru/article/n/institutional-context-for-entrepreneurshipin-emerging-economies-a-nine-country-comparison-of-university-students-perceptions (20.09.2020). 
Estrin, S., Korosteleva, J., \& Mickiewicz, T. (2013). Which institutions encourage entrepreneurial growth aspirations? Journal of Business Venturing, 28(4), 564-580.

Fedirko, O. (2014). Key trends and problems of regional innovation system's development in Poland and Ukraine. Central European Business Review, 3(3), 38-45.

Fishbein, M., \& Ajzen, I. (1975). Belief, attitude, intention and behavior: An introduction to theory and research. New York: Addison-Wesley.

Fishbein, M., \& Ajzen, I. (1980). Understanding attitudes and predicting social behavior. Englewood Cliffs, NJ: Prentice Hall.

Foo, M. D., Knockaert, M., Chan, E. T., \& Erikson, T. (2016). The individual environment nexus: Impact of promotion focus and the environment on academic scientists' entrepreneurial intentions. IEEE Transactions on Engineering Management, 63(2), 213-222.

Gartner, W. B., Bird, B. J., \& Starr, J. (1992). Acting as if: Differentiating Entrepreneurial from organisational Behavior. Entrepreneurship Theory and Practice, 16(3), 13-32.

Goel, R. K., Goktepe-Hulten, D., \& Ram, R. (2015). Academics' entrepreneurship propensities and gender differences. Journal of Technology Transfer, 40(1), 161-177.

Goethner, M., Obschonka, M., Silbereisen, R. K., \& Cantner, U. (2012). Scientists' transition to academic entrepreneurship: Economic and psychological determinants. Journal of Economic Psychology, 33, 628-641.

Gupta, V. K., Guo, C., Canever, M. et al. (2014) Institutional environment for entrepreneurship in rapidly emerging major economies: the case of Brazil, China, India, and Korea. International Entrepreneurship and Management Journal, 10, 367-384. https://doi.org/10.1007/s11365-0120221-8.

Haeussler, C., \& Colyvas, J. A. (2011). Breaking the ivory tower: Academic entrepreneurship in the life sciences in UK and Germany. Research Policy, 40(1), 41-54.

Hair, J. F., Jr., Black, W., Babin, B., Anderson, R. E., \& Tatham, R. (2006). Multivariate data analysis (6th ed.). New Jersey: Prentice Hall

Hair, J. F., Jr., Black, W. C., Babin, B. J., \& Anderson, R. E. (2010). Multivariate data analysis: A global perspective (7th ed.). Upper Saddle River, New Jersey: Pearson Education International, Prentice Hall.

Hayter, C. S. (2015). Public or private entrepreneurship? Revisiting motivations and definitions of success among academic entrepreneurs. The Journal of Technology Transfer, 40(6), 1003-1015.

Hayton, J. C., George, G., \& Zahra, S. (2002). National culture and entrepreneurship: A review of behavioral research. Entrepreneurship Theory and Practice, 26(4), 33-51.

Hederson, R., \& Robertson M. (2000). Who Wants to be An Entrepreneur? Young Adult Attitudes to Entrepreneurship as A Career. Career Development International, 5(6), 279-287.

Holienka, M., Gál, P., \& Kovačičová, Z. (2017). Drivers of Student Entrepreneurship in Visegrad Four Countries: Guesss Evidence. Central European Business Review, 6(2), 54-63. doi: 10.18267/j.cebr.180.

Hoppmann, J., \& Vermeer, B. (2020). The double impact of institutions: Institutional spillovers and entrepreneurial activities in the solar photovoltaic industry. Journal of Business Venturing, 35(3), 105960. https://doi.org/10.1016/j.jbusvent.2019.105960. 
Hu, L., \& Bentler, P. M. (1999). Cut-off criteria for fit indexes in covariance structure analysis: Conventional criteria versus new alternatives. Structural Equation Modeling, 6(1), 1-55.

Jang, S.M., Sohn, S., \& Yu, M. (2018). Perceived stress, alcohol consumption, and Internet use among Korean college students: Does sensation-seeking matter? Children and Youth Services Review, 88, 354-360.

Jöreskog, K. G., \& Sörbom, D. (1993). LISREL VIII: A guide to the program and applications, 3rd Ed. Chicago: SPSS.

Kruja-Demneri, A. (2020). Entrepreneurial Orientation, Synergy and Firm Performance in the Agribusiness Context: An Emerging Market Economy Perspective. Central European Business Review, 9(1), 56-75. https://doi.org/10.18267/j.cebr.229.

Krueger, N. F. (2000). The cognitive infrastructure of opportunity emergence. Entrepreneurship Theory and Practice, 24(3), 5-23. https://doi.org/10.1007/978-3-540-485438_9.

Kondratiuk-Nierodzińska, M. (2016). Innovation capabilities in EU countries: have Central and Eastern European countries been catching up?. Journal of Business Economics and Management, 17(5), 765-779, https://doi.org/10.3846/16111699.2015.1114016.

Kolvereid, L. (1996). Organisational employment versus self-employment: Reasons for career intentions. Entrepreneurial Theory and Practice, 23(3), 23-31.

Kostiva, T. (1997). Cross-cultural reliablility and validity of a scale to meaure firm entrepreneurial orientation. Journal of Business Venturing, 12, 213-225.

Lam, A. (2001). What motivates academic scientists to engage in research commercialisation: "Gold", "ribbon" or "puzzle"? Research Policy, 40(10), 1354-1368.

Lee, L., Wong, P., Foo, M., \& Leung, A. (2011). Entrepreneurial intentions: the influence of organisational and individual factors. Journal of Business Venturing, 6(1), 124-136.

Li, C., \& Morgan, G. (2010). From knowledge to product: Institutional change and commercialisation of university research in China, Journal of Science and Technology Policy in China, 1(3), 254-274.

Liñán, F. (2008). Skill and value perceptions: How do they affect entrepreneurial intentions? International Entrepreneurship and Management Journal, 4(3), 257-272.

Link, A. N., Siegel. D. S., \& Bozeman, B. (2007). An empirical analysis of the propensity of academics to engage in informal university technology transfer. Industrial and Corporate Change, 16(4), 641655.

Lissoni, F. (2012). Academic patenting in Europe: An overview of recent research and new perspectives. World Patent Information, 34, 197-205.

Long, T. Q., \& Quan, T. H. M. (2018). Do gender and age make a difference in entrepreneurial intention of Vietnamese adults, Global Journal of Advanced Research, 5(1), 10-16.

Luthje, C., \& Franke, N. (2003). The making of entrepreneur: testing a model of entrepreneurial intent among engineering students at MIT. $R \& D$ management, 33(2), 135-47.

Maresch, D. Harms, R., Kailer, N., \& Wurm, W. B. (2015). The impact of entrepreneurship education on entrepreneurial intention of students in science and engineering versus business studies university programs. Technological Forecasting \& Social Change, 104,172-192.

Markman, G. D., Siege, D. S., \& Wrigh, M. (2008). Research and technology commercialisation. Journal of Management Studies, 45(8), 1401-1423. 
Manev, I. M., \& Manolova, T. S. (2010). Entrepreneurship in emerging economies: Review and integration of two decades of research, Journal of Developmental Entrepreneurship, 15(1), 69-99.

Minniti, M., \& Nardone, C. (2007). Being in someone else's shoes: The role of gender in nascent entrepreneurship. Small Business Economics, 28(2-3), 223-238.

Miranda, F. J., Chamorro-Mera, A., \& Rubio, S. (2017). Academic entrepreneurship in Spanish universities: An analysis of the determinants of entrepreneurial intention. European Research on Management and Business Economics, 23, 113-122.

Misoska, A. T., Dimitrove, M., \& Mrsik, J. (2016). Drivers of entrepreneurial intentions among business students in Macedonia. Economic Research, 29(1), 1062-1074.

MOET. (2018). Education and Training Statistical Year-Book Academic Year 2017-2018. Hanoi: Vietnam Education Publishing House.

Mosey, S., \& Wright, M. (2007). From human capital to social capital: A longitudinal study of technology based academic entrepreneurs. Entrepreneurship Theory and Practice, 31, 909-935.

Moog, P., Werner, A., Houweling, S., \& Backes-Gellner, U. (2015). The impact of skills, working time allocation and peer effects on the entrepreneurial intentions of scientists. The Journal of Technology Transfer, 40(3), 493-511

Mowery, D. C., \& Sampat, B. N. (2005). The Bayh-Dole Act of 1980 and university-industry technology transfer: a model for other OECD governments? Journal of Technology Transfer, 30, 115-127.

Mueller, S.L., \& Thomas, A. S. (2001). Culture and entrepreneurial potential: A nine country study of locus of control and innovativeness. Journal of Business Venturing, 16(1), 51-75.

Nguyen, V. T., Nguyen, T. L., \& Nguyen, H. H. (2018). Fostering academic entrepreneurship: A qualitative study of invention commercialisation. Journal of Development Entrepreneurship, 23(4), 1-23.

Nguyen, T., Nguyen, L., Bryant, S., \& Nguyen, H. (2020). What motivates scientists in emerging economies to become entrepreneurs? Evidence from Vietnam. Sustainability, 12(3), 1-18.

Nguyen, H.X., Tran, L.H., \& Nguyen, T. L. H. (2020). Solutions to promote commercialisation of research results in Vietnamese Universities. Journal of Business and Economic Development, 5(2), 82-89.

Nunnally, J. C., \& Bernstein, I. H. (1994). The Assessment of Reliability. Psychometric Theory, 3, 248292.

North, D. (1990). Institutions, Institutional Change and Economic Performance. Cambridge, MA: Cambridge University Press.

Nowiński, W., Haddoud, M. Y., Wach, K., \& Schaefer, R. (2020). Perceived public support and entrepreneurship attitudes: A little reciprocity can go a long way!. Journal of Vocational Behavior. 121, 103474. https://doi.org/10.1016/j.jvb.2020.103474.

O'Gorman, C., Byrne, O., \& Pandya, D. (2008). How scientists commercialise new knowledge via entrepreneurship. The Journal of Technology Transfer, 33(1), 23-43.

Oftedal, E. M., lakovleva, T., \& Foss, L. (2017). University context matter: An institutional perspective on entrepreneurial intentions of students. Education and Training. https://doi.org/10.1108/ET-06-20160098

Othman, N., \& Mansor, M. (2012). Entrepreneurial intentions among polytechnic students in Malaysia. International Business Management, 6(4), 517-526. 
Perkmann, M., Tartari, V., McKelvey, M., Autio, E., Brostrom, A., \& Hughes, A. (2013). Academic engagement and commercialisation: A review of the literature on university - industry relations. Research Policy, 42(2), 423-442.

Peng, M. W., \& Zhou, J. Q. (2005). How network strategies and institutional transitions evolve in Asia. Asia Pacific Journal of Management, 22, 321-326.

Phan, P., \& Siegel, D. S. (2006). The effectiveness of university technology transfer: Lesson learned. Managerial and policy implications, and the road forward. Foundations and Trends in Entrepreneurship, 2(2), 77-144.

Phan, Q. N., \& Ho, T. N. (2014). Exploitation and Commercialisation of Inventions towards Green Economy. Journal of Business and Economics, 5(12), 2400-2405. https://doi.org/10.15341/jbe(2155-7950)/12.05.2014/020.

Pinho, J. C., \& de Lurdes Martins, M. (2020). The opportunity to create a business: Systemic banking crisis, institutional factor conditions and trade openness. Journal of International Entrepreneurship. https://doi.org/10.1007/s10843-020-00275-3.

Powers, J. B. \& McDougall, P. P. (2005). University start-up formation and technology licensing with firms that go public: A resource-based view of academic entrepreneurship. Journal of Business Venturing, 20(3), 291-311.

Preacher, K. J., \& Hayes, A. F. (2008). Asymptotic and resampling strategies for assessing and comparing indirect effects in multiple mediator models. Behavior Research Methods, 40(3), 879-891. https://doi.org/10.3758/BRM.40.3.879.

Radosevic, L. (2017). Upgrading technology in Central and Eastern European economies. IZA World of Labor, 338. https://doi.org/10.15185/izawol.338

Reynolds, P. D., Camp, S. M., Bygrave, W., Autio, E., \& Hay, M. (2001). Global Entrepreneurship Monitor 2001 Executive Report. Babson College, Kauffman Center for Entrepreneurial Leadership, and London Business School.

Rondinelli, D. A., \& Kasarda, J. D. (1992). Foreign trade potential, small enterprise development and job creation in developing countries. Small Business Economics, 4, 253-265.

Riviezzo, A., Santos, S., Liñán, F., Napolitano, M. R., \& Fusco, F. (2019). European universities seeking entrepreneurial paths: The moderating effect of contextual variables on entrepreneurial orientationperformance relationship. Technological Forecasting and Social Change, 141, 232-248, https://doi.org/10.1016/j.techfore.2018.10.011.

Salkind, N. J. (2010). Encyclopedia of research design (Vols. 1-0). Thousand Oaks, CA: SAGE Publications, Inc. https://doi.org/10.4135/9781412961288.

Schillo, R. S., Persaud, A., \& Jin, M. (2016). Entrepreneurial readiness in the context of national systems of entrepreneurship. Small Business Economics, 46, 619-637.

Shane, S. (2000). Prior knowledge and the discovery of entrepreneurial opportunities. Organization Science, 11(4), 448-469.

Shane, S., \& Venkataraman, S. (2000). The promise of entrepreneurship as a field of research. Academy of Management Review, 25(1), 217-226.

Shapira, P., \& Wang, J. (2009). From lab to market? Strategies and issues in the commercialisation of nanotechnology in China. Asian Business \& Management, 8(4), 461-489.

Shirokova, G., Osiyevskyy, O., Bogatyreva, K., Edelman, L. F., \& Manolova, T. S. (2020). Moving from Intentions to Actions in Youth Entrepreneurship: An Institutional Perspective. Entrepreneurship 
Research Journal (published online ahead of print 2020), 20190201. https://doi.org/10.1515/erj2019-0201.

Smallbone, D., \& Welter, F. (2012). Entrepreneurship and institutional change in transition economies: The Commonwealth of Independent States, Central and Eastern Europe and China compared. Entrepreneurship \& Regional Development, 24(3-4), 215-233.

Smallbone, D., Welter, F., \& Ateljevic, J. (2020). Entrepreneurship in emerging market economies: Contemporary issues and perspectives. International Small Business Journal, 32, 113-116.

Shrout, P. E., \& Bolger, N. (2002). Mediation in experimental and nonexperimental studies: New procedures and recommendations. Psychological Methods, 7(4), 422445. https://doi.org/10.1037/1082-989X.7.4.422.

Spencer, J., \& Gomez, C. (2003). The relationship among institutional structures, economic factors, and domestic entrepreneurial activity: A multi country study. Journal of Business Research, 57(10), 1098-1107.

Teixeira, A. A., \& Nogueira, J. (2016). Academic entrepreneurship in life sciences: The case of a moderate innovator country. Journal of Developmental Entrepreneurship, 21(1), 1650004.

Tran, N. C. (2007). Turning science into business in developing countries: the case of vaccine production in Vietnam. The Journal of Technology Transfer, 32(4), 425-434.

Tran, T. A., \& Kocaoglu, D. F. (2009). Review of government technology transfer in Vietnam, PICMET Conference, IEEE, 2849-2857. https://doi.org/10.1109/PICMET.2009.5261770.

Tsai, K. H., Chang, H. C., \& Peng, C. Y. (2014). Extending the link between entrepreneurial self-efficacy and intention: A moderated mediation model. International Entrepreneurship and Management Journal, 12, 445-463.

Turulja, L., Veselunovic, L., Agic, E., \& Pasic-Mesihovic, A. (2020). Entrepreneurial intention of students in Bosnia and Herzegovina: what type of support matters? Economic Research-Ekonomska Istraživanja, https://doi.org/10.1080/1331677X.2020.1730216

Turker, D., \& Selcuk, S. S., (2009). Which factors affect entrepreneurial intention of university students? Journal of European Industrial Training, 33(2), 142-159.

Urban, B. (2019). The influence of the regulatory, normative and cognitive institutions on entrepreneurial orientation in South Africa. The International Journal of Entrepreneurship and Innovation, 20(3), 182-193. https://doi.org/10.1177/1465750318796721.

Vamvaka, V., Stoforos, C., Palaskas, T., \& Botsaris, C. (2020). Attitude toward entrepreneurship, perceived behavioral control, and entrepreneurial intention: dimensionality, structural relationships, and gender differences. Journal of Innovation and Entrepreneurship, 9 (5), 1-26 https://doi.org/10.1186/s13731-020-0112-0.

Vancea, M., \& Utzet, M. (2017). Does Unemployment and Precarious Employment Lead to Increasing Entrepreneurial Intentions among Young People? Results from a Survey-Based Study in Spain. Central European Business Review, 6(2), 5-17. https://doi.org/10.18267/j.cebr.176.

Veciana, J. M., \& Urbano, D. (2008). The institutional approach to entrepreneurship research. Introduction. International Entrepreneurship and Management Journal, 4(4), 365379. https://doi.org/10.1007/s11365-008-0081-4

Vodopivec, M. (1998). Turning the unemployed into entrepreneurs: An evaluation of a self-employment program in a transitional economy. Journal of Developmental Entrepreneurship, 3(1), 71-96.

Welter, F., \& Smallbone, D. (2011). Institutional perspectives on entrepreneurial behavior in challenging environments. Journal of Small Business Management, 49(1), 107-125. 
Wisła, R., \& Sierotowicz, T. (2015). Patent licensing in selected European Countries. Journal of Entrepreneurship Management and Innovation, 11(3), 67-88.

Wu, Y., Welch, E., \& Huang, W. L. (2015). Commercialisation of university inventions: Individual and institutional factors affecting licensing of university patents. Technovation, 36, 1225. https://doi.org/10.1016/j.technovation.2014.09.004

Yaacob, N. A., Rasli, M. A., Senin, A., \& Othman, S. N. (2011). Perceptions of commercialisation activities of research results among academic researchers in Malaysia. American Journal of Economics and Business Administration, 3(1), 24-32.

The research paper passed the review process. | Received: July 17, 2020; Revised: September 21, 2020; Accepted: October 25, 2020; Pre-published online: February 8, 2021; Published in the regular issue: September 20, 2021. 